\title{
Cytokines and apoptosis genes polymorphisms influence the outcome of hepatitis $C$ virus infection
}

\author{
L Ksiaa-Cheikh Rouhou ${ }^{*}$, I Sfar ${ }^{1}$, H Aounallah-Skhiri ${ }^{2}$, H Aouadi ${ }^{1}$ S Jendoubi-Ayed ${ }^{1}$, T Ben Abdallah'1, \\ K Ayed $^{1}$, Y Lakhoua-Gorgi ${ }^{1}$
}

From 5th European Workshop on Immune-Mediated Inflammatory Diseases

Sitges-Barcelona, Spain. 1-3 December 2010

\section{Introduction}

Chronic hepatitis C virus (HCV) infection persists despite the presence of specific humoral and cellular immune [1-2] responses and the factors leading to viral clearance or persistence are poorly understood [3-6].

\section{Aim}

To investigate the possibility of a significant relationship between outcome of HCV infection and cytokines/apoptosis genes polymorphisms.

\section{Materials and methods}

The polymorphisms of genes: IL-1 (-889 IL- $1 \alpha,-511$ and +3954 IL-1 $\beta$, IL-1-Ra), IL-18 (-137 and -607), IL-12p40 $(-1188)$ and Apo1/Fas (-670) were determined by PCRRFLP, PCR-SSP and PCR-VNTR; in 100 Tunisian hemodialysed patients infected by the HCV and 100 healthy blood donors. The patients were classified in two groups: G1 included 76 active chronic hepatitis patients (positive RNA-HCV) and G2: 24 hemodialysed having eliminated spontaneously virus (negative RNA-HCV).

\section{Results}

The univariate analyze of the genotypes and alleles frequencies of the cytokines polymorphisms studied do not reveal any positive or negative association statistically significant with the outcome of the HCV infection. Nevertheless, the frequency of genotype association [-37GC/-607CA] IL-18 is statistically higher among G2 patients $(41,7 \%)$ compared to that at G1 hemodialysed $(15,8 \%)(\mathrm{p}=0,008$, OR: $0.26,95 \% \mathrm{CI}:[0.10-0.73]) . \mathrm{We}$

${ }^{1}$ Immunology Research Laboratory of Kidney Transplantation and Immunopathology (LR03SP01), Charles Nicolle Hospital, Tunisia Full list of author information is available at the end of the article found also, a significant increased frequency of AA genotype of Apo1/Fas gene in G2 patients $(41,6 \%)$ than in G1 $(17,5 \%)(p=0,026, \mathrm{OR}=3,49,95 \%$ CI $[1,13-10,69])$. Adjustment for known covariates factors (age, gender and genotypes) confirmed these univariate findings and revealed that the genotype association GC-CA of (-137and-607) IL-18 gene and AA genotype of Apo1/Fas gene were associated to the clearance of $\mathrm{HCV}(\mathrm{p}=0.041$ and $\mathrm{p}=0.017$ respectively).

\section{Conclusion}

In Tunisian hemodialysed patients, spontaneous clearance of HCV seems to be associated with the two genotypes GC-CA of (-137and-607) IL-18 polymorphism and the AA genotype of Apol /Fas gene.

\section{Author details}

${ }^{1}$ Immunology Research Laboratory of Kidney Transplantation and Immunopathology (LRO3SP01), Charles Nicolle Hospital, Tunisia. ${ }^{2}$ National Health Institute, Tunisia.

Published: 25 November 2010

\section{References}

1. Pawlotsky JP: Virus de l'hépatite $C$ et réponse immunitaire. Gastroenterol Clin Biol 2001, 25:B123-B133.

2. Thimme R, Bukh J, Spangenberg C, Wieland S, Pemberton J, Steiger C, Govindarajan RHPurcell, Chisari FV: Viral and immunological determinants of hepatitis C virus clearance, persistence, and disease. Proc Natl Acad Sci USA 2002, 99(24):15661-15668.

3. Smith AJP, Humphries SE: Cytokine and cytokine receptor gene polymorphisms and their functionality. Cytokine \& Growth Factor Reviews 2009, 20:43-59.

4. Constantini PK, Syczewska MW, Clare M, Boron KA, Mc Farlane IG, Cramp ME, Donaldson PT: IL1, IL10, and TNFa gene polymorphisms in hepatitis $C$ virus infection : an investigation of the relationships with spontaneous viral clearance and response to interferon therapy. Liver 2002, 22(5):404-12. 
5. Yin $L M$, Zhu WF, Wei $L$, Xu XY, Sun $D G$, Wang $Y B$, Fan $W M$, Yu $M$, Tian $X L$, Wang QX, Gao Y, Zhuang H: Association of interleukin 12 p40 gene 3' untranslated region polymorphism and outcome of HVC infection. World J Gastroenterol 2004, 10(16):2330-2333.

6. Choi C, Benveniste E: Fas ligand/Fas system in the brain: regulator of immune and apoptotic responses. Brain Research Reviews 2004, 44:65-81.

doi:10.1186/1479-5876-8-S1-P8

Cite this article as: Ksiaa-Cheikh Rouhou et al: Cytokines and apoptosis genes polymorphisms influence the outcome of hepatitis $C$ virus infection. Journal of Translational Medicine 2010 8(Suppl 1):P8.

Submit your next manuscript to BioMed Central and take full advantage of:

- Convenient online submission

- Thorough peer review

- No space constraints or color figure charges

- Immediate publication on acceptance

- Inclusion in PubMed, CAS, Scopus and Google Scholar

- Research which is freely available for redistribution

Submit your manuscript at www.biomedcentral.com/submit
C Biomed Central 